maNet in BC that's been in place longer than anywhere else in Canada. I want to see the data from PharmaNet in my electronic medical record, and then I can use that data to generate prescriptions."

But while proponents contend that eprescribing will yield faster filling of prescriptions and fewer medication errors, some Canadian researchers are skeptical.

There is little solid evidence demonstrating that e-prescribing makes a difference, says Allen Huang, associate profes- sor of medicine at McGill University in Montréal, Quebec, whose study of 28 physicians and 3400 patients found that computerization had little impact on reducing prescribing errors ( $\mathrm{J} \mathrm{Am} \mathrm{Med}$ Inform Assoc. 2008;15:430-38).

Other studies have similarly concluded that there is weak evidence that e-prescribing reduces prescription error rates (J Popul Ther Clin Pharmacol 2010;17:e243-e255 and J Eval Clin Pract 2011; doi:10.1111/j.1365-2753
.2011.01655.x.[Epub ahead of print, Mar. 18]), although the latter study found that it does increase the number of phone calls to physicians from pharmacists seeking clarification. "Physicians don't feel this has any yield," says coauthor Merrick Zwarenstein, a senior scientist at the Institute for Clinical Evaluative Sciences in Toronto, Ontario." Paul Christopher Webster, Toronto, Ont.

CMAJ 2011. DOI:10.1503/cmaj.109-3980

\title{
Medical podcasts going viral
}

$\mathrm{W}$ ho would have thought it possible? A podcast on gallstones or appendicitis going viral? Or at least what passes for going viral in the sequestered world known as undergraduate medical education.

Yet, a podcast produced at the faculty of medicine at the University of Alberta in Edmonton appears to be doing just that.

More than 50 episodes of "Surgery 101 " have been downloaded by students and others in 116 countries. "It took us about 16 months to get our first 100000 downloads and that was in February. And we're about to get our second 100 000 downloads and that's between February and June," says developer Dr. Jonathan White, director of surgical education at the University of Alberta.

As of late August, there were 58 episodes of Surgery 101, each offering a 10-20 minute address on a topic such as "evidence-based medicine and its use in surgery ... damage control surgery ... (and) orthopedic emergencies."

The episodes can be directly downloaded from http://surgery101.libsyn .com/ or are available for free on iTunes (http://itunes.apple.com/ca /podcast/surgery-101/id293184847). A new one is posted each Friday.

So popular is the podcast becoming that Spanish translations may be in the offing, White says, as an old colleague now working in Mexico has expressed an interest in translating the episodes into Spanish for use by people in Central and South America. It's a trend that White would like to see expanded. 'I'd like to see more initiatives like that of

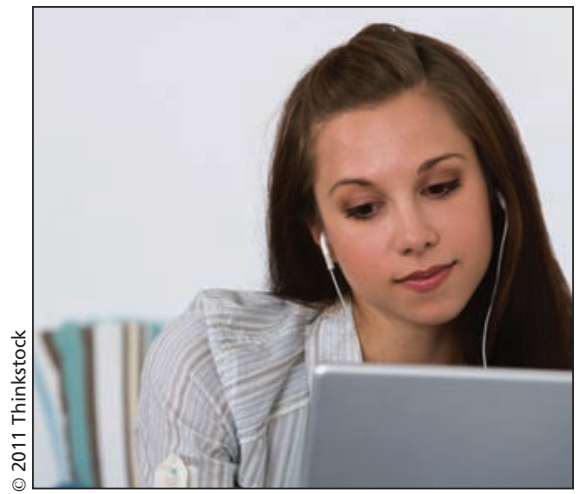

Medical students can now use online stories to obtain basic information on different surgical topics.

people making their own materials."

That would include patients and students themselves, White adds, noting that he's recently been approached by representatives of both groups inquiring as to whether they might produce new episodes from their perspective.

Patients' perspectives would be invaluable as their views are often overlooked, White says. "I think medical students sometimes get lost in the medical side of things and it's all about diseases and all that kind of stuff, and it'd be nice to hear from an actual patient who's having the surgery we're talking about or dealing with the disease we're talking about."

That the podcast is freely available is only appropriate, White says. "We're here in North America. We're in a very privileged position and we have all this expertise. I think we should give it away to people who actually need it so that's a way that our experts can actually contribute to the well-being of someone in Africa or South America. We've got our local surgeons here talking to people all across the world."

It all started in 2008 with the notion of a developing an electronic learning resource that would give students basic information on different surgical topics. White says he was long interested in using technologies as pedagogical tools. "It's a way to spread your wings and do something different as an educator."

The first episode, entitled "What is Surgery 101?" was produced in conjunction with general surgeon Dr. Parveen Boora, then a fourth-year resident who wanted to help as part of his research elective.

Boora was immediately attracted to the idea when White mentioned it in a presentation on surgical education. Under supervision, Boora recorded and edited episodes 2-10. The first was narrated by White.

"It was a project sort of intended for consumption by our med students and stuff, but we just thought we'd stick it out there for free, so it's pretty gratifying that other people find it useful," Boora says.

The first 10 episodes were put online in the fall of 2008 and the project was put on hold for a year. But it was resurrected when international interest began soaring. "We started getting emails from people we had never heard of before," White says. "People were asking when we were going to make more."

White re-initiated the project, producing some episodes on his own and calling on colleagues at the university and at Edmonton's Royal Alexandra Hospital to address such topics as coronary artery 
bypass grafting and liver transplantation. Now there's a three-month wait for people willing to help record an episode and actually getting it online.

Many of the episodes deliberately use humour to engage viewers, White says. In episode 14 on problems with the prostate, for example, he advises listeners to first use the bathroom because the entire session is punctuated "with sounds of a toilet flushing or with water dripping."

Such unusual sound effects are often used as transition cues from one topic to another within an episode, says Todd Penney, a third-year medical student at the University of Alberta. "I think they're a great tool to use to study for exams and to get a general knowledge base of each of the different types of problems that can present to a general surgeon, and how they can deal with them."

The "personality" within a podcast certainly makes it a more enjoyable and effective pedagogical tool than a textbook, says Erik Beuker, a general surgery resident in Edmonton, Alta. Sometimes the speaker has "little personal anecdotes to add that you wouldn't really find in a textbook, or even some humour ... or a strategy to help you remember something or focus on what's sort of the essential information," he says. - Erin Walkinshaw, Ottawa, Ont.

CMAJ 2011. DOI:10.1503/cmaj.109-3955

\section{More news online}

A pack a day: Just what the doctor ordered?: Smokers in Iceland may soon need a doctor's note to light up. Member of Parliament and former health minister Siv Fridleifsdottir, backed by the country's medical association, will table a private member's bill in the fall to make cigarettes a prescription-only product (www.cmaj.ca/lookup/doi/10.1503/cmaj.109-3969). - Lauren Vogel, CMAJ

\section{Company profits from side-effects of glaucoma} treatment: A medication used to treat openangle glaucoma is being swept off pharmaceutical shelves because one of its side-effects, longer eyelashes, has cosmetic appeal (www .cmaj.ca/lookup/doi/10.1503/cmaj.109-3919). Adrianna Banaszek, Coldstream, BC

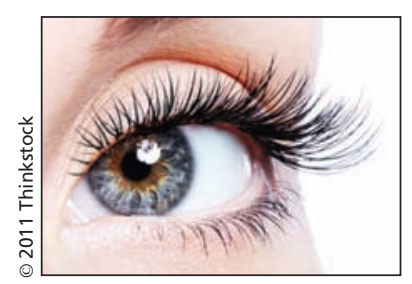

iPhone app an aid in diagnosing concussions: Developers of an iPhone application for recognizing concussions say it could be a useful tool in the absence of medical professionals (www.cmaj.ca/lookup/doi/10.1503/cmaj .109-3942). - Erin Walkinshaw, Ottawa, Ont.

Provincial squeeze on generic prices continues: The clampdown on generic drug payments is becoming a nation-wide vise as Nova Scotia has joined the bevy of provinces who'll reduce prices paid for knockoffs (www.cmaj.ca /lookup/doi/10.1503/cmaj.109-3966). — donalee Moulton, Halifax, NS

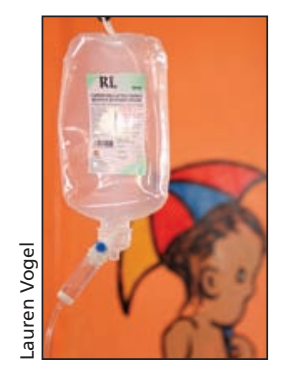

Rwanda moving to provide "good deaths" for terminally ill: Rwanda has committed to provide all citizens living with incurable illnesses, as well as their families and caregivers, with high-quality, affordable palliative care services to meet their physical, psychological, social and spiritual needs by 2020 (www.cmaj.ca/lookup/doi/10.1503 /cmaj.109-3963). — Lauren Vogel, CMAJ

CMAJ 2011. DOI:10.1503/cmaj.109-3999 